\title{
PERLINDUNGAN KONSUMEN ATAS KERUSAKAN/KEHILANGAN PAKAIAN PADA JASA USAHA LAUNDRYDI DENPASAR
}

\author{
I Komang Dodik Wijaya, I Nyoman Putu Budhiarta, Putu Ayu Sriasih Wesna \\ Fakultas Hukum Universitas Warmadewa, Denpasar-Bali, Indonesia \\ Wijaya@gmail.com, budhiarta1@gmail.com, sriasih@gmail.com
}

\begin{abstract}
Abstrak
Saat ini semakin canggihnya teknologi menciptakan suatu penyewaan jasa terbaru seperti Laundry. UU No 8 Tahun 1999 tentang Perlindungan Konsumen dapat menjadi landasan bagi konsumen dan lembaga perlindungan konsumen untuk memberdayakan dan melindungi kepentingan konsumen, serta membuat pelaku usaha lebih bertanggung jawab. Peneltian ini bertujuan untuk mendalami perlindungan hukum terhadap konsumen Laundry atas kerusakan/kehilangan barang dan menjelaskan pertanggungjawaban pelaku usaha Laundry atas kerusakan/kehilangan barang. Penelitian ini menggunakan penelitian hukum empiris. Adapun sumber data yang digunakan yaitu data primer dan sekunder. Data diperoleh melalui teknik wawancara dan dokumentasi selanjutnya diolah dan dianalisis dengan menggunakan teknik pengolahan data secara kualitatif. Hasil penelitian menunjukkan bahwa Konsumen yang dirugikan atas kelalaian pelaku usaha dapat meminta pertanggungjawaban dari pelaku usaha yang merugikannya, serta menuntut ganti rugi atas kerugian yang dialaminya, hal ini sebagaimana telah dinyatakan dalam Pasal 7 huruf G UUPK. Bentuk pertanggungjawaban pelaku usaha laundry berbeda-beda antara pelaku usaha. Dalam hal pemberian ganti rugi kepada konsumen, pelaku usaha sesuai dengan Pasal 19 UUPK harus memberikan ganti rugi selambat-lambatnya 7 hari, apabila melewati batas waktu tersebut maka konsumen dapat menggugat pelaku usaha.
\end{abstract}

Kata kunci: Perlindungan Konsumen; Pakaian; Laundry

\begin{abstract}
Currently increasingly sophisticated technology creates a new rental service such as laundry. Law No. 8 of 1999 on Consumer Protection can be a foundation for consumers and consumer protection agencies to empower and protect consumer interests, and to make business actors more responsible. This research aims to explore legal protection for laundry consumers for damage / loss of goods and to explain the responsibilities of laundry business actors for damage/loss of goods. This study uses empirical legal research. The data sources used are primary and secondary data. Data obtained through interview and documentation techniques then processed and analyzed using qualitative data processing techniques. The results of the research show that consumers who have been harmed by the negligence of the business actor can hold the business actor accountable for him, as well as claim compensation for the losses they have suffered, this is as stated in Article 7 letter G UUPK. The form of accountability of laundry business actors varies between business actors. In the case of giving compensation to consumers, the business actor in accordance with Article 19 of the UUPK must provide compensation not later than 7 days, if it passes the time limit, the consumer can sue the business actor.
\end{abstract}

Keywords: Consumer Protection; Clothes; Laundry

\section{PENDAHULUAN}

Seiring perkembangan zaman akan semakin memberikan tantangan baru pada setiap elemen masyarakat mulai dari interaksi sosial, ekonomi, politik dan pemerintah. Hal ini sering dialami konsumen, pelaku usaha maupun sebagai pemerintah. Sehingga dampak yang ditimbulkan harus mendapat perhatian yang sangat serius dari berbagai pihak. Usaha tidak terlepas dengan namanya pelaku usaha dan konsumen kedua unsur ini saling berhubungan dan akan membuat sebuah perjanjian (Muaziz \& Busro, 2015).

Undang-undang telah memberikan perlindungan yang adil serta perlakuan yang sama dihadapan hukum. Di indonesia saat ini hak perlindungan konsumen mendapatkan perhatian yang sangat serius, dikarenakan dalam hal perlindungan konsumen sebelum dirumuskan dalam Undangundang No. 8 Tahun 1999. banyak sekali para pelaku usaha melakukan hal-hal diluar batas kewajaran terhadap konsumen baik berupa memberikan harga yang tinggi atau hanya dapat mencari 
barang yang dicari disatu tempat saja ada, ini terjadi karena dianggap konsumen berada pada posisi yang lemah (Juwariyah, 2010).

Sehingga setelah dimuat dalam UUPK dapat meningkatkan harkat dan martabat konsumen. Pelaku usaha dituntut agar melakukan tanggungjawab apabila merugikan konsumen. Kelalaian atau masalah yang dilakukan oleh para pelaku usaha laundry seperti kerusakan dan/atau kehilangan pakaian, harus bertanggung jawab kepada konsumen dengan melakukan ganti rugi (Yuliastari et al.,2018). Sekalipun telah dirumuskandalam UUPK, namu masih banyak pelaku usaha tidak mentaati isi dari UUPK. Berdasarkan wawancara dengan konsumen yang dirugikan ada yang diberi pertanggungjawaban atas kehilangan pakaiannya yaitu sebesar 5 (lima) kali ongkos cuci pakaian tersebut. Sehingga para konsumen masih sangat dirugikan atas kelalaian para pelaku usaha laundry di Kota Denpasar tersebut.

Pelaksanaan tanggung jawab pemilik usaha laundry tidak dilaksanakan sebagaimana yang telah ditentukan dalam Undang-Undang Perlindungan Konsumen. Faktor penyebab tidak dilaksanakan tanggung jawab bahwa tidak ada kesadaran hukum dari pelaku usaha, karena sifat dari pelaku usaha yang selalu mencari keuntungan, jika memberi ganti kerugian pada konsumen maka pelaku usaha mengalami keuntungan yang kecil (Andhika, 2014a). Menurut Rahmat, (2016) bahwa Pembentukkan pola kontrak dan klausula baku diperkuat oleh emahnya wawasan pelaku usaha tentang norma perlindungan konsumen dan memuncaknya kepentingan-kepentingan bisnis pelaku usaha, konsumen belum sepenuhnya terlindungi. Segala kerusakan dan kehilangan pakaian milik konsumen harus ditanggung penuh oleh pemilik jasa laundry sekalipu tidak membayar seluruhnya disesuaikan dengan kebijakan antara pelaku usaha dan konsumen (Andhika, 2014b). Penelitian ini bertujuan untuk mendalami perlindungan hukum terhadap konsumen Laundry atas kerusakan/kehilangan barang dan menjelaskan pertanggungjawaban pelaku usaha Laundry atas kerusakan/kehilangan barang

\section{METODE PENELITIAN}

Penelitian ini didesai dengan penelitian yang dipergunakan adalah penelitian hukum empiris. Mengenai sumber data yang digunakan terbagi atas sumber data primer, yaitu data yang diperoleh dari para pihak yang menjadi obyek penelitian ini sedangkan sumber data sekunder, yaitu data yang diperoleh melalui studi kepustakaan. Pengumpulan data dilakukan melalui wawancara, yaitu teknik pengumpulan data yang dilakukan dengan cara tanya jawab yang berlangsung satu arah untuk tujuan tertentu selanjutnya dokumentasi yaitu, mencari data mengenai variable berupa catatan, buku, surat kabar dan lain-lain. Data tersebut selanjutnya diolah dan dianalisis dengan menggunakan teknik pengolahan data secara kualitatif (Sugiyono, 2013).

\section{HASIL DAN PEMBAHASAN}

\section{Dasar Hukum Perlindungan Terhadap Konsumen Laundry Atas Kerusakan/Kehilangan Barang}

Undang- uandang Perlindungan Konsumen bisa dikatakan hal yang cukup baru. Menurut Miru \& Yodo, (2004) Perkembangan Perlindungan Konsumen yang paling berarti dengan lahirnya UUPK, yang memberikan perlindungan konsumen untuk mencegah timbulnya kerugian konsumen. Pelaku usaha saat iini banyak memanfaatkan situasi dan kondisi dalam masyarakat untuk tidak lagi memenuhi kewajibannya untuk memberikan ganti rugi atas kerugian yang ditimbulaknnya kepada konsumen. hal ini berdasarkan prinsip ekonomi yaitu mendapatkan keuntungan sebesar-besarnya dengan modal yang sedikit mungkin. Dalam UUPK konsumen diberikan hak untuk meminta pertanggungjawaban atas kerugian yang ditimbulkan oleh pelaku usaha serta menuntut ganti rui atas kerugian yang dialaminya, hal ini diatur dalam Pasal 7 huruf G UUPK. Dalam menjalankan suatu pekerjaan, pelaku usaha dan konsumen berkewajiban menjalankan kesepakatan yang telah dibuat sebelumnya. Jika salah satu pihak tidak menjalankan kesepakatan yang telah dibuat maka telah dikatan pihak tersebut melakukan wanprestasi, dengan ini jika salah satu pihak melakukan wanprestasi maka pihak yang lain akan menuntut pihak yang melakukan kelalaian tersebut (Rambut Lupiyoadi, 2006: 7).

Hubungan hukum antara konsumen dan pelaku usaha didasarkan pada struk pembayaran yang akan menimbulkan perikatan. Maka jika salah satu pihak melanggar akan dapat dituntut ganti rugi. 
Berkenaan tanggungjawab pelaku usaha yang melakukan kelelaian yang menyebabkan konsumen dirugikan terdapat lima prinsip pertanggungjawaban, yaitu:

1. Prinsip tanggungjawab berdasarkan kesalahan

2. Prinsip praduga untuk selalu bertanggungjawab

3. Prinsip untuk selalu tidak bertanggungjawab

4. Prinsip tanggungjawab mutlak

5. Prinsip tanggungjawab dengan pembatasan.

Prinsip ini digunakan untuk mengantisipasi pelaku usaha agar meminimalisir kesalahan atau kelalaian yang merugikan konsumen sehingga para. Kelalaian pelaku jasa usaha laundry, terdiri dari beberapa bentuk kelalaian yaitu, yaitu salah menghitung jumlah pakaian konsumen, salah menghitung biaya yang harus dibayarkan oleh konsumen, Pakaian konsumen tertukar dan Pakaian konsumen hilang dan/atau luntur warnanya.

Lebih lanjut konsumen menjelaskan ada beberapa faktor yang dapat menyebabkan para pelaku usaha dapat melakukan kesalahan sebagai berikut

a. Terlalu banyaknya konsumen datang bersamaan saat ingin melaundry.

b. Pemilik usaha laundry tidak mempekerjakan tenaga kerja yang cukup sehingga mengalami masa krodit saat mencatat.

c. Pemilik usaha belum mau menggunakan sistem teknologi untuk mempermudah tenaga kerjanya untuk mencatatkan baik jumlah pakaian ataupun jumlah yang harus dibayarkan konsumen.

Konsumen menjelaskan lebih lanjut bahwa jika telah terjadi kelalaian atau wanprestasi maka para pelaku usaha laundry tersebut akan membayar ganti rugi karena telah melakukan kelalaian dalam menjalankan usahanya. Sesuai dengan perjanjian yang telah masing-masing pihak sepakati dalam nota pembayaran.

\section{Pertanggungjawaban Pemilik Usaha Laundry Atas Kerusakan/Kehilangan Barang Konsumen}

Bentuk pertanggungjawaban dan ganti rugi yang diberikan oleh pelaku usaha laundry di Kota Denpasar dalam praktiknya terhadap konsumen berbeda- beda antara satu tempat laundry dengan tempat laundry lainnya adalah sebagai berikut:

a. Terjadinya baju hilang

Pelaku usaha laundry di Green Laundry akan mengganti dengan lima kali ongkos cuci pakaian tersebut. Pada pelaku usaha Anugerah laundry dan Sari Nusa laundry akan mengganti dengan setengah harga pakaian yang hilang. Sedangkan pada Harmonis laundry mengganti dengan sejumlah uang seharga dengan baju yang hilang tersebut.

b. Terjadinya baju rusak atau sobek

Hal ini biasanya terjadi pada saat pencucian berlangsung, para pelaku usaha laundry tidak akan menerima pakaian yang kemungkinan besar akan mengalami kerusakan karena lapuk, tetapi apabila terjadi akibat kelalaian maka akan diberikan ganti rugi. Pada pihak pelaku jasa usaha laundry di Green Laundry akan mengganti kerugian sebesar lima kali ongkos cuci. Pada pelaku usaha Anugerah laundry dan Sari Nusa laundry akan diberikan kompensasi sebesar setengah harga pakaian tesebut. Sedangkan pada Harmonis laundry diganti dengan seharga pakaian yang mengalami kerusakan tersebut.

c. Terjadinya baju terkena noda

Biasanya pelaku usaha mengecek dahulu apakah ada baju yang dari awalnya memang sudah terkena noda atau tidak. pada Green Laundry akan mengganti dengan lima kali ongkos cuci pakaian tersebut. Pada pelaku usaha Anugerah laundry dan Sari Nusa laundry akan mengganti dengan setengah harga pakaian yang terkena noda. Sedangkan pada Harmonis laundry mengganti dengan sejumlah uang seharga dengan baju yang terkena noda tersebut.

d. Terjadinya baju tertukar

Biasanya pelaku usaha menghubungi konsumen lain yang pada hari itu juga mencucikan bajunya ditempat yang sama dengan konsumen yang merasa bajunya hilang atau tertukar, apakah ada baju tambahan pada saat mengambil laundry, kalau ada maka pihak pelaku usaha akan mengambilnya. Jika tidak ada maka pihak Green Laundry akan mengganti dengan lima kali ongkos cuci pakaian tersebut. Pada pelaku usaha Anugerah laundry dan Sari Nusa laundry akan mengganti dengan setengah harga pakaian yang tertukar. Sedangkan pada Harmonis laundry mengganti dengan sejumlah uang seharga dengan baju yang tertukar tersebut 
e. Terjadinya keterlambatan penyelesaian

Hal ini biasanya terjadi karena banyaknya baju yang harus di laundry dan juga kadang karena musim penghujan. Tetapi pelaku usaha menjanjikan secepat mungkin untuk segera menyelesaikannya.

Bentuk tanggungjawab tersebut dilakukan secara baik oleh pelaku usaha laundry di Kota Denpasar, tanggungjawab yang berdasar atas ketentuan- ketentuan yang dibuat oleh pelaku usaha laundry di Kota Denpasar itu sendiri dan disamping itu juga tetap memperhatikan ketentuanketentuan UUPK. Apabila pelaku usaha laundry di Kota Denpasar menimbulkan kerugian kepada konsumen, maka harus dipertimbangkan kemungkinan terdapatnya peluang untuk meminta pertanggungjawaban para pihak yang terlibat dalam kegiatan bisnis laundry di Kota Denpasar, terutama pelanggaran-pelanggaran terhadap ketentuan yang terdapat dalam UUPK (Lupiyoadi, 2018).

Meskipun sering kali adanya seruan mengenai perlunya peraturan perundang-undangan yang komprehensif sejak lama namun kurangnya kesadaran tentang pentingnya perlindungan konsumen membuatnya kebanyakan pelaku usaha memanfaatkan tersebut untuk mengelabui konsumen atau berbuat sewenang-wenang yang bisa merugikan konsumen (Nugroho, 2008).

Konsumen yang dirugikan menyadari bahwa pada dasarnya konsumen memiliki hak ganti rugi dari perbuatan pelaku jasa usaha laundry yang melakukan kerugian kerugian terhadap pakaian konsumen, tetapi konsumen mendapatkan ganti rugi yang tidak setara nilainya dengan kerugian yang dialami konsumen, seperti yang dinyatakan oleh pihak yang dirugikan dari pelaku usaha jasa laundry mendapat ganti rugi yang nilainya sebesar Rp. 5.000 (lima ribu rupiah) padahal harga pakaian yang dihilangkan sebesar Rp. 150.000 (seratus lima puluh ribu rupiah), disinilah letak ketidak setaraan antara kerugian dan pemberian ganti rugi oleh pelaku usaha jasa laundry. Pelaku usaha jasa laundry dalam memberikan ganti rugi tetap mempertahankan terhadap klausula eksonersi yang dibuatnya dan konsumen harus menerima aturan yang telah dibuat sepihak oleh pelaku usaha jasa laundry, padahal sudah jelas UUPK melarang pelaku usaha membuat perjanjian yang hanya menguntungkan usahanya tanpa memperhantikan hak- hak konsumen. Konsume meminta ganti rugi terhadap kehilangan dan kerusakan pakaian mereka yang disebabkan oleh pelaku usaha jasa laundry, pelaku usaha menjanjikan akan memberi pembayaran ganti rugi dalam jangka waktu 1 (satu) bulan, akan tetapi menurut mereka jangka waktu ganti rugi selama 1 (satu) bulan sangat lama. Sedangkan menurut UUPK batas waktu paling lama untuk meberikan ganti rugi yaitu 7 (tujuh) hari.

Upaya penyelesaian sengketa antara konsumen dengan pelaku usaha pada umumnya konsumen lenih memilih menyelesaikan sengketa secara jalur kekeluargaan. Hal ini menunjukan bahwa tingkat toleransi konsumen cukup tinggi karena konsumen cenderung menghindari terjadinya sengketa yang berkepanjangan, melihat keadaan tersebut maka hak-hak konsumen tidak terpenuhi menurut UUPK. Mediasi merupakan upaya hukum yang sering konsumen lakukan ketika hak-hak konsumen dirugikan oleh pelaku usaha. Sehingga banyak konsume yang mengganggap jalur hukum untuk menggugat pelaku usaha akan memerlukan waktu yang lama. Ada beberapa faktor penyebab konsumen tidak mau menggugat pelaku usaha laundry yaitu:

1. Kurangnya kesadaran hukum mengenai perlindungan konsumen, bahwa konsumen kurang memahami keberadaan peraturan perundang-undangan yang dapat melindungi hak-hak konsumen. khususnya Undang-Undang Nomor 8 Tahun 1999 Tentang Perlindungan Konsumen serta konsumen kurang teliti terhadap pelaku usaha jasa laundry yang memberikan pelayanan, keamanan, kenyamanan dan kepuasan dalam mengembangkan usahanya. Sehingga konsumen hanya pasrah terhadap pemberian ganti rugi yang tidak setara nilainya dengan kerugian yang dialami konsumen.

2. Karna tingkat toleransi konsumen yang sangat tinggi, konsumen beranggapan masalah kehilangan dan kerusakan pakaian miliknya bukan hal yang perlu diperkarakan, cukup menjadi pelajaran bagi konsumen agar lebih teliti memilih usaha jasa laundry yang memberikan kenyamanan dan kepuasan kepada konsumen.

\section{SIMPULAN DAN SARAN}

\section{Simpulan}

Berdasarkan hasil analisis sata dapat disimpulkan bahwa dengan lahirnya Undang-Undang Perlindngan Konsumen (UUPK) yang memberikan perlindungan kepada konsumen tidak hanya 
dalam bidang materiil, tetapi juga dalam bidang hukum formal. Sebagai konsekuensi hukum dari pelanggaran yang diberikan oleh UUPK, konsumen yang dirugikan atas kelalaian pelaku usaha dapat meminta pertanggungjawaban dari pelaku usaha yang merugikannya, serta menuntut ganti rugi atas kerugian yang dialaminya, hal ini sebagaimana telah dinyatakan dalam Pasal 7 huruf G UUPK., yang ang kedua Bentuk pertanggungjawaban pelaku usaha laundry berbeda-beda antara pelaku usaha, ada yang memberikan penggantian kerusakan dan/atau kehilangan pakaian sebesar 5 kali ongkos cuci, setengah harga pakaian dan sebesar pakaian tersebut. Bentuk tanggungjawab tersebut dilakukan secara baik oleh pelaku usaha laundry di Kota Denpasar, tanggungjawab yang berdasar atas ketentuan-ketentuan yang dibuat oleh pelaku usaha laundry di Kota Denpasar itu sendiri dan disamping itu juga tetap memperhatikan ketentuan-ketentuan UUPK. Dalam UUPK Bab VI Pasal 19 sampai dengan Pasal 28 UUPK, mengatur mengenai tanggungjawab perdata dari pelaku usaha terhadap konsumennya. Dalam hal pemberian ganti rugi kepada konsumen, pelaku usaha sesuai dengan Pasal 19 UUPK harus memberikan ganti rugi selambat-lambatnya 7 hari, apabila melewati batas waktu tersebut maka konsumen dapat menggugat pelaku usaha.

\section{Saran}

Berdasarka hasil analisis data peneliti meberi saran yaitu bagi pelaku usaha jasa laundry di Kota Denpasar harus berusaha menjaga kepercayaan konsumen dan lebih meningkatkan kualitas pelayanan terutama keamanan dan kenyamanan konsumen, sehingga konsumen lebih percaya terhadap jasa laundry yang diberikan dan pelaku usaha diharapkan mematuhi peraturan perundang-undangan yang berlaku sehingga dalam menjalankan usahanya pelaku usaha lebih memahami tanggungjawab yang harus dipenuhi, yang kedua Hendaknya pelaku usaha jasa laundry di Kota Denpasar menetapkan peraturan tentang harga maksimal untuk biaya ganti rugi yang ditimbulkannya, sehingga pihak konsumen maupun pelaku usah sendiri mendapatkan kepastian tentang biaya ganti rugi dan tidak ada dari pihak manapun yang merasa dirugikan.

\section{DAFTAR PUSTAKA}

Andhika, M. (2014a). Perlindungan Konsumen atas Hilang dan Rusaknya Pakaian Konsumen pada Jasa Usaha Laundry di Aceh Besar. E-Jurnal GLoria Yuris Prodi Ilmu Hukum UNTAN, 2(3), 126-133.

Andhika, M. (2014b). Tanggung Jawab Pengusaha Jasa Laundry Matuary Waia Terhadap Kerusakan dan Kehilangan Pakaian Milik Konsumen di Kota Pontianak. E-Jurnal GLoria Yuris Prodi Ilmu Hukum UNTAN, 2(3).

Juwariyah. (2010). Hukum Perjanjian. Teras.

Lupiyoadi, R. (2018). Manajemen Pemasaran Jasa. Salemba empat.

Miru, A., \& Yodo, S. (2004). Hukum Perlindungan Konsumen. Rajawali Pers.

Muaziz, M. H., \& Busro, A. (2015). Pengaturan Klausula Baku dalam Hukum Perjanjian untuk Mencapai Keadilan Berkontrak. Law Reform, 11(1), 74.

Nugroho, S. A. (2008). Proses Penyelesaian Sengketa Konsumen. Kencana Medua Group.

Rahmat. (2016). Korelasi Antara Ancaman Klausula Baku dan Kritik Terhadap Undang-Undang Perlindungan Konsumen. Khatulistiwa, 6(2), 33-36.

Sugiyono. (2013). Metode Penelitian Pendidikan Pendekatan Kuantitatif dan Kualitatif. Alfabeta.

Yuliastari, K. T., Adnyani, N. K. S., \& Sudiatmaka, K. (2018). Tanggung Jawab Pelaku Usaha Jasa Laundry terhadap Kerugian Konsumen di Kabupaten Buleleng. Journal Komunitas Yustisia Universitas Pendidikan Ganesha Jurusan Ilmu Hukum, 1(3), 228-238.

Undang-Undang Dasar Negara Republik Indonesia Tahun 1945.

Kitab Undang-Undang Hukum Perdata

Undang-Undang Negara Republik Indonesia Nomor 8 Tahun 1999 tentang Perlindungan Konsumen 